\title{
The University and the Rediscovery of Teaching: A System-Level Model
}

\section{John Bailiff and Susan Kahn}

The University of Wisconsin System

In the recent report of the Carnegie Foundation for the Advancement of Teaching, College: The Undergraduate Experience in America, Dr. Ernest Boyer concludes that undergraduate education today is in a "troubled" condition. One source of the trouble, according to the findings cited in the report, lies in the emphasis upon research and professional training-and the corresponding de-emphasis on undergraduate education-that has come to dominate our universities and faculties. According to this argument, generations of training graduate students to engage exclusively in research and of tenuring those faculty members who devote themselves chiefly to scholarship have contributed to the inadequacy of the education we now offer most of our undergraduate students.

College and university governing boards and state legislatures have reacted to the current sense of crisis in undergraduate education by increasing their demands for the measurement and evaluation of teaching and learning. But such measures, however well-intentioned, are unlikely to lead to real improvement unless they are supplemented by a genuine effort within the universities themselves to restore teaching to its place as the central focus of the university's enterprise. Within the University of Wisconsin System, such an effort has been spearheaded during the past ten years by the Undergraduate Teaching Improvement Council (UTIC). 


\section{A STATEWIDE PROJECT}

UTIC differs from campus-level instructional development centers such as the one at the University of Washington described by Jody Nyquist in last year's edition of To Improve the Academy. Staff in such centers typically function as consultants to departments and individual faculty members seeking solutions to specific curricular or pedagogical problems. Some centers also conduct orientations for new faculty members, maintain libraries of instructional resource materials, and provide other direct services to their faculties.

By contrast, UTIC functions at the system level as an advocate for undergraduate teaching improvement and as an administrative unit that proposes, plans and coordinates systemwide teaching improvement and faculty development initiatives. Its purview includes not only such primarily research-oriented institutions as the UW-Madison and the UW-Milwaukee, but also eleven four-year campuses and thirteen two-year centers whose missions focus explicitly on undergraduate education.

As UTIC's programs, funding levels and visibility within the UW System have grown over the course of its history, it has become increasingly effective in its role of focusing faculty and administrative attention on the university's teaching mission. Accordingly, we are convinced that UTIC and its programs represent a viable model for state university systems committed to improving the quality of undergraduate education. The brief history of UTIC provided below is intended to illuminate how a successful and multifaceted program evolved from a modest grant program initiated sixteen years ago.

\section{THE UNDERGRADUATE TEACHING IMPROVEMENT GRANT PROGRAM}

In 1971, the University of Wisconsin set aside funds of $\$ 180,000$ to create the Undergraduate Teaching Improvement Grant Program. The first grants were awarded in the 1971-72 academic year. The program continued after the 1973 merger of the primarily undergraduate system of Wisconsin State Universities with the doctoral campuses of the University of Wisconsin in Madison and Milwaukee; this merger formed the present University of Wisconsin, a centrally administered system of thirteen universities, thirteen two-year centers, and an extension service. 
Over the years since the inception of the grant program, the number and variety of proposals has continued to grow. In most years, twenty to twenty-five proposals are funded from among up to sixty submissions to the System Grant Review Committee. Over its sixteen-year history, the Undergraduate Teaching Improvement Grant Program has provided over 500 system faculty members, representing virtually every academic discipline, with an opportunity to try out innovative teaching ideas, to experiment with educational applications of new technologies, and to work with faculty memivers on other UW campuses to develop new programs for improving teaching and learning. Grant recipients are required to present the results of their projects to other system faculty members and to make any products of the grant available to their colleagues throughout the system; these requirements help to ensure that as many faculty members and students as possible will benefit from successful grant projects.

A particularly valuable feature of the grant program has been a special category of grants that permits institutions to apply for funds to create campus centers for teaching improvement and instructional development. Several campuses have taken advantage of this opportunity. The UW-Milwaukee's Center for the Improvement of Instruction (CII), in operation since 1981, continues to offer new programs and services to a growing clientele. The CII's recent projects include training programs for foreign teaching assistants and an annual orientation for all new instructional staff. Last year, it hosted a regional conference on cooperative learning techniques, which grew out of a seminar offered to UTIC's Faculty College. The UWWhitewater's Teaching Enhancement Center (TEC), founded with an Undergraduate Teaching Improvement Grant in 1984, offers numerous workshops each year on such topics as grant writing, testing and grading, interactive teaching, and critical thinking. The TEC's lunchtime series, "Talking on Teaching," provides regular opportunities for faculty members across disciplines to discuss teaching issues of mutual concern.

The Undergraduate Teaching Improvement Grant program has had other important results. The campus screening committees originally established to review grant proposals at the campus level have in many cases expanded their roles to include other faculty development and teaching improvement activities. 
Many Undergraduate Teaching Improvement Grant projects have served as models for programs on other campuses, both within and outside the system, while in other cases, grant recipients have gone on to win extramural grants to continue or expand programs begun with Undergraduate Teaching Improvement Grants. The grant program also offers reward and recognition for faculty members awarded grants; on most campuses in the system, Undergraduate Teaching Improvement Grants are now routinely considered in promotion and tenure decisions. Finally, the grant program provides a valuable first experience in proposal writing for many junior faculty members in the system.

Indeed, one testimony to the success of the grants is that, despite tight budgets throughout the UW System, funding for the program has been substantially increased for the 1987-1988 academic year. The additional funds will be used to create a new category of matching grants designed to permit faculty to attract extramural funds for teaching improvement and curricular development into the system.

\section{THE UNDERGRADUATE TEACHING IMPROVEMENT COUNCIL}

As the grant program became increasingly popular, the interchange among campus grant review committees, system review committees, grant recipients and other faculty began to afford a voice and a forum for the many UW faculty members engaged primarily in undergraduate instruction. This growing interest in undergraduate teaching led in 1977 to the formation of a new group, the Undergraduate Teaching Improvement Council. Composed of one faculty and one administrative representative appointed for three-year terms from each institution of the System, together with several student members, the Council is administered by a half-time Executive Director also selected for a three-year term from among interested teaching faculty. With the help of a small permanent staff provided by the UW System Office of Academic Affairs, the Council administers the grant program, disseminates the results of grant projects, and seeks new ways to address the interests and concerns of faculty teaching undergraduates. 


\section{CONFERENCES AND FACULTY COLLEGE}

The first projects of the Council were conferences and workshops on undergraduate teaching issues. In most academic years, the Council sponsors two or three systemwide conferences, which are typically planned by faculty committees convened for the purpose. Recent conference topics have included issues in foreign language instruction, critical thinking, and teaching in science laboratories; upcoming conferences will focus on teaching in the fine arts, strategies for internationalizing the curriculum, the assessment of learning, and student advising. Some conferences, such as those on international education and assessment, are designed to coincide with system initiatives; others grow out of suggestions received from faculty members or proposed by Council representatives.

In addition to exposing faculty members to new teaching ideas to bring back to their classrooms and to their colleagues, the conferences play an important role in promoting systemwide collegiality. In many cases, interests generated and shared at UTIC conferences have led to formal interinstitutional cooperation among faculty members in a particular discipline. The Council encourages such cooperation by providing funds and staff support for faculty workshops, retreats, and regional meetings intended to follow up on issues raised at the systemwide conferences.

In June 1979, the Council sponsored the first Faculty College, which has since become the centerpiece of the Council's annual programs. Each year, Faculty College affords seventy to eighty faculty members the opportunity to participate in two three-day seminars on teaching issues and to engage in the intense and varied conversation about teaching that the concentrated and collegial atmosphere provides. Recent Faculty College seminars have focused on such issues as teaching writing across the curriculum, improving students' problem-solving abilities, fostering a cooperative learning environment in the classroom, planning a faculty career path and addressing the needs of the women who form the majority of our undergraduate population.

Participants in Faculty College find that the experience of the College inspires them to reflect anew on their roles as educators and the values they bring to those roles. They report that the College revives their enthusiasm for teaching, 
and, at the same time, provides them with specific ideas and approaches to try out in the classroom. As in the case of the conferences, the Council provides funding for regional workshops growing out of seminars and discussions at Faculty College.

\section{THE WISCONSIN TEACHING FELLOWS}

In 1982, a proposal written by the Council's Executive Director and funded by the Lilly Foundation created a program of fellowships for young faculty that is sponsored and administered by the Undergraduate Teaching Improvement Council. At the end of the three-year period of the Lilly grant, the UW System Office of Academic Affairs continued support for the project, which is now called the Wisconsin Teaching Fellows Program. Each year, up to thirty fellows are selected from among applicants in their first ten years of college teaching. They receive released time and travel funds to pursue projects related to their teaching and to convene in a Summer Institute devoted to the discussion of their work and of issues related to undergraduate teaching.

The two weeks of the institute, together with attendance at Faculty College and other conferences during the year, offer fellows an opportunity to articulate and debate conceptions of teaching and interpretations of education at an early point in their careers. In a recent report to the Lilly Foundation, the director of the program noted that fellows began their year with the usual professional and scholarly presuppositions about the importance of research projects and publishable papers. But after the experience of the institute, the fellows found the complexity and challenge of teaching itself restored to the center of their concerns; this development undoubtedly owed much to the interdisciplinary nature of the group, which encouraged fellows to go beyond narrow professional concerns and to consider teaching issues common to a wide variety of disciplines. One indication of the value of the Wisconsin Teaching Fellows Program is that a number of former fellows have gone on to win outstanding teaching awards on their campuses and to become campus leaders in faculty development and teaching improvement. 


\section{DISSEMINATION OF TEACHING IDEAS}

One of the most important objectives of the Undergraduate Teaching Improvement Council is to inform faculty about teaching innovations and ideas that result from grant projects, conferences, and other activities. In addition, the Council serves as an agency for communication among campuses about projects and programs concerning faculty development and teaching improvement.

UTIC achieves these aims primarily through its publications. Undergraduate Teaching Improvement Grant Abstracts summarizes the results of grant projects. New Directions In the Classroom is a catalogue of products that have resulted from grant projects. These products include videotapes, computer software, manuals, and other materials; they are made available to all system faculty at cost. Both publications are updated annually and can be consulted in campus libraries and departmental offices.

Twice each semester, through a newsletter called UTIC $T A L K$, the Council publicizes its programs, campus teaching improvement events, and other resources. UTIC's semiannual journal, Teaching Forum, publishes articles on teaching by system faculty members. The intent of Teaching Forum is to encourage faculty to write about their teaching and about their teaching-related research. Both UTIC TALK and Teaching Forum are sent to all faculty and administrators in the system. The quality of these publications has been improved during the past two years, especially through better selection, review, and editing of papers for Teaching Forum. Comments from faculty and requests for additional copies for use as examples and assignments indicate that it is beginning to receive a respectful reading.

Most universities provide some awards for excellence in teaching. Faculty selected for such awards in the University of Wisconsin System are contacted by UTIC with a request for a paper on their work. The articles that result are considered for publication in Teaching Forum.

The programs of the Undergraduate Teaching Improvement Council now serve more than 250 teaching faculty members annually. By extension, this represents an audience of some 30,000 undergraduates each year. The Undergraduate Teaching Improvement Grant Program, administered by UTIC, annually 
awards more than $\$ 210,000$ in grants to faculty members seeking support for projects related to their teaching or for meetings and workshops devoted to teaching issues. Up to 30 young faculty members are selected each year as Wisconsin Teaching Fellows. To these figures must be added the many faculty members served by UTIC conferences and by the campus instructional development centers created and coordinated with the support of UTIC. In addition, all faculty and instructional staff in the system receive UTIC's newsletter and journal.

Objective assessment of the total impact of UTIC's diverse array of programs is difficult, although virtually all grant projects, conferences and other activities are evaluated individually. Perhaps the best evidence for the overall effectiveness of our programs can be found in the steadily increasing demand for the resources we offer. Grant applications and conference participation continue to grow year by year, while administrative recognition of this growth has led to substantial funding increases in recent years, in spite of tight budgets across the UW System.

Most important, the systemwide focus of UTIC has helped to make the most of scarce resources and to create an environment on the campuses that is conducive to the recognition of teaching excellence. If it is true that recognizing and rewarding good teaching leads to teaching improvement, then UTIC indeed represents an effective approach to reversing the muchpublicized erosion in the quality of college education. 